\title{
Differences in the contributions of elements of service to satisfaction, commitment and consumers' share of purchase: A study from the tetraclass model \\ Received (in revised form): 24th November, 2002
}

\section{Fabrice Clerfeuille}

is a senior lecturer of marketing at the University of Nantes in France and his research topics concern the construct of attitude and the satisfaction concept.

\section{Yannick Poubanne}

is a doctoral student at the University of Aix-Marseille III in France, focusing on the relationship between client satisfaction and loyalty.

\begin{abstract}
In this paper, the authors examine the contribution of elements of service to satisfaction, loyalty and consumer purchase behaviour. Loyalty is defined in this study as the consumer's commitment to the company and the purchase behaviour as his share of purchase in this company. Analysis is based on Llosa's tetraclass model which is tested for a complex offer of service in a healthcare area and broadened to client commitment and share of purchase.
\end{abstract}

\section{INTRODUCTION}

There is much research on consumer satisfaction in service marketing. It reflects the importance of this concept for companies who often link it with brand loyalty (or loyalty to the supplier) and with customer behaviour. The hypothesis of the relationship between satisfaction, loyalty and buying behaviour therefore remains controversial. For some authors, customer satisfaction, loyalty and buying behaviour are closely linked. ${ }^{1,2}$ For others there are no significant relationships between the three concepts. ${ }^{3,4}$ Given the works of Llosa, ${ }^{5,6}$ Bartikowski and Llosa ${ }^{7}$ and Lichtlé et al., that have shown that the elements having an effect on customer satisfaction could have different modes of contribution, the authors have duplicated this hypothesis simultaneously to the three concepts of satisfaction, commitment (one of the loyalty components) and share of purchase. Among the different models permitting the test of this hypothesis, the tetraclass one has been selected for its superiority and its mapping which enable easy visualisation of the contribution of elements of service to satisfaction, commitment and share of purchase.

The objective of this paper is to compare the contribution of some variables to satisfaction, commitment and share of purchase in a company. Do the explanatory variables of consumer 


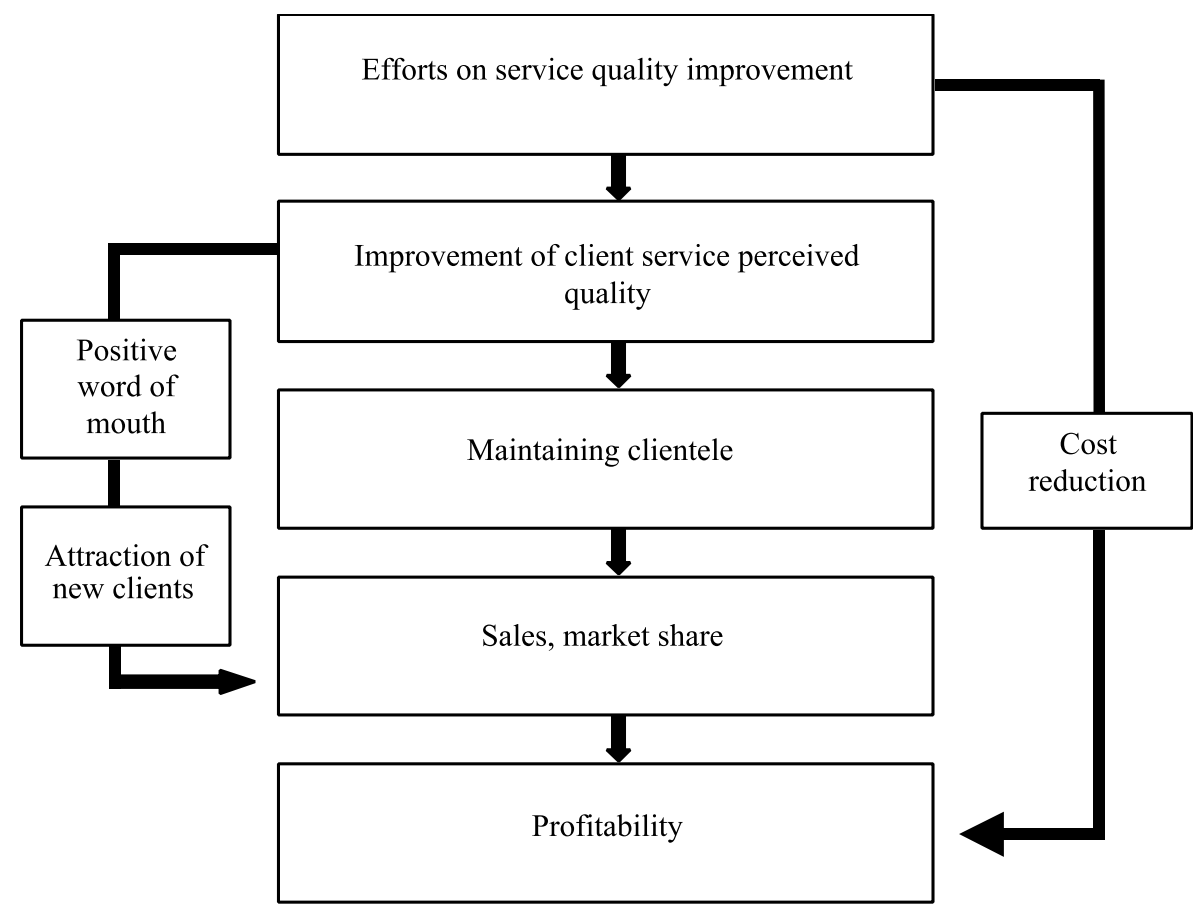

Figure 1 Model of service quality and profitability improvement

satisfaction have the same influence on consumer commitment towards a company and on the share of purchase?

As well as the replication of the tetraclass satisfaction model in a new area of service, this study also allows the identification of the relative contribution of the analysed criteria to consumer commitment and purchase behaviour. Managerial implications, based on the similarity of the contribution modes of the explanatory variables of these three concepts, also emerge.

\section{CONCEPTUAL FRAMEWORK OF SATISFACTION, COMMITMENT AND PURCHASE BEHAVIOUR}

There are multiple definitions of customer satisfaction depending on the researcher's point of view: a cognition, an emotion, an outcome of an affective or cognitive process or, according to the approach adopted, it can be a transactional or relational definition. ${ }^{9}$ For the present research, the authors favour the definition given by Garbarino and Johnson who consider it 'a post-purchase immediate evaluative judgment or an affective reaction towards the transaction with the most recent firm' ${ }^{10}$ Since the initial works of Jacoby and Kyner, ${ }^{11}$ brand loyalty has been described as being made up of two components: an attitudinal one (called 'commitment' by the authors) and a behavioural one (the purchase itself). This paper will keep this dual structure of brand loyalty and extend it to loyalty to service suppliers.

Customer satisfaction, loyalty towards a firm and purchase behaviour are closely linked in many research articles. ${ }^{12,13}$ Rust et al. ${ }^{14}$ connect these three concepts in the following way: the more the customer satisfaction increases, the stronger their loyalty to the firm and the more they will tend to favour purchases in this company in this service or product category (see Figure 1).

According to this research stream, the 
finding of the criteria of customer satisfaction towards a company, associated with action for improvement of these criteria, must generate higher customer loyalty towards the company and higher share of purchase. The authors will successively present in this part the theoretical elements justifying the selected choices of analysis of the concepts of satisfaction (with the tetraclass model), of loyalty to the service supplier (with its commitment component) and of purchase behaviour (with share of purchase).

\section{SATISFACTION}

In line with many authors, ${ }^{15-17}$ Llosa's work $^{18,19}$ gives prominence to the fluctuating weights of the elements intervening in customer satisfaction. Among four categorisation methods of elements of service contributing to customer satisfaction, Bartikowski and $\operatorname{Llosa}^{20}$ indicate the superiority of the tetraclass model of categorisation based on five criteria:

- the contributions to satisfaction of elements of service depend on the positive or negative performance of the element

- the borders between the categories of elements are defined clearly and non-arbitrarily

- ordinal types of data are sufficient to obtain robust results

- the tetraclass model allows the visual mapping of the contributions

- the tetraclass model relies on a client's live service experience and not on a simulation.

This is why this model has been chosen in the authors' research for, first, client satisfaction and then client attitudinal and behavioural loyalties.

In this tetraclass model, four modes of element contributions to the service experience are described:

- basic elements contribute strongly to the global client dissatisfaction level when unfavourably evaluated. When favourably evaluated, they contribute slightly to client satisfaction;

- plus elements contribute strongly to the global client satisfaction level when favourably evaluated. When unfavourably evaluated, they contribute slightly to client satisfaction;

- key elements contribute strongly to the global client satisfaction level however they are evaluated by the client;

- secondary elements have no prime role in client satisfaction whatever their evaluation.

The tetraclass model tested in different areas such as car loans, catering ${ }^{21,22}$ or food distribution ${ }^{23}$ underlines the possible categorisation of the different elements of service in each sector. In the suggested future areas of research, the need to validate this categorisation by replicating the research in different fields and in different service experiences, notably in companies delivering a complex offer of services, comes out.

\section{LINKS BETWEEN SATISFACTION AND LOYALTY}

For some authors, customer satisfaction is a precondition to customer loyalty towards the company. ${ }^{24-32}$ Other research has underlined correlations between high levels of satisfaction and higher consumer loyalty. ${ }^{33-36}$

For others, however, the links between satisfaction and loyalty are not so linear. For instance, Bloemer and Kasper $^{37}$ show in their study that there is 
Contribution of the element to the client level of satisfaction

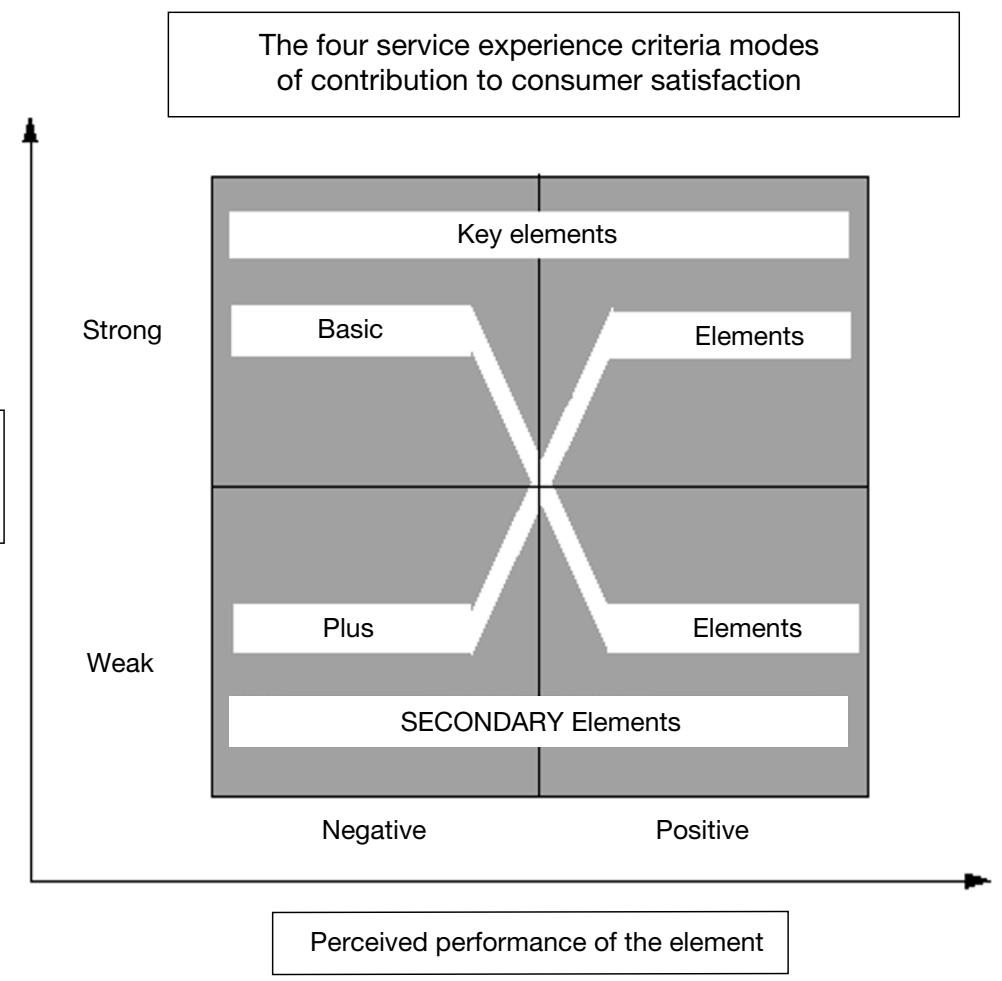

Figure 2 The tetraclass model identifies four service experience criteria modes of contribution to consumer satisfaction $^{18}$

no systematic and significant relationship between satisfaction and loyalty. Garbarino and Johnson ${ }^{38}$ underline the different impact of satisfaction on loyalty depending on the selected approach, relational or transactional. Anderson and Mittal $^{39}$ and Jones and Sasser ${ }^{40}$ indicate that the consumer level of loyalty is higher for 'very satisfied' than for 'satisfied' customers.

The authors arguing the linearity between satisfaction and loyalty suggest three satisfaction thresholds corresponding to three levels of loyalty: ${ }^{41-44}$

- a level of dissatisfaction accompanied by non-loyalty

- a level of medium satisfaction accompanied by a stable level of loyalty

- a level of high satisfaction for which consumers would express a very strong loyalty.
The description of these levels of satisfaction and loyalty evokes similarities with the categories of the satisfaction elements of the tetraclass model. These variables can be thought of as the same:

- those primarily influencing consumer dissatisfaction (the 'basic criteria' of the tetraclass model) and those explaining consumer disloyalty;

- those primarily acting on consumer satisfaction (the 'plus criteria' of the tetraclass model) and those explaining strong consumer loyalty. The plus criteria could be the pleasant surprises for the client which would generate the 'delight' mentioned by Ngobo in this phase.

These remarks as a whole are consistent with Audrain and Evrard's view ${ }^{45}$ that researchers disagree on the role of satisfaction as an antecedent of loyalty, 
and suggest further study of the links between satisfaction and loyalty. Rather than trying to measure the links between satisfaction and the loyalty construct as a whole, a possible source of controversy between researchers, this study has been limited to the links between satisfaction, commitment and consumers' share of purchase. Thus the authors have retained the attitudinal and behavioural components of loyalty, taking into account their key roles as described by other authors. ${ }^{46-50}$

This paper will focus on the study of the links between satisfaction and commitment, analysing the similarity or the difference between the elements intervening in consumer satisfaction and loyalty towards a service company.

\section{LINKS BETWEEN SATISFACTION, LOYALTY AND SHARE OF PURCHASE}

The links between consumer satisfaction with a company and the consumer's share of purchase in the company as well as between consumer loyalty to a company and share of purchase in the company, go against the same remarks as those presented earlier between satisfaction and loyalty. The complexity of the relationship between these three concepts gives results which are contradictory depending on the authors. For example, some authors suggest links between consumer satisfaction and share of purchases from the studied companies. ${ }^{51-54}$ Ngobo $^{55}$ underlines that, once again, a linear process between the concepts of satisfaction and product repurchase, stands as a framework of the analysis in some works, but this has not been checked.

The links between consumer satisfaction and the two other concepts, consumer commitment and purchase behaviour in the company, must be retrieved in the elements of service evaluated by the consumer. In this paper the authors focus on the study of the links between these three concepts by means of the contribution of elements of service to satisfaction: is the contribution of elements of service to satisfaction the same for client commitment to the company and for that client's share of purchase in this company?

\section{HYPOTHESES AND METHODOLOGY}

A set of hypotheses is generated from the above conceptual framework. The hypotheses will be tested in a very different area of service to Llosa's, in order to validate, or not, the tetraclass model in the case of a complex offer of service. In this case the service chosen is in the medical sector, because of the high level of consumer involvement. (Not, however, the human medical sector because of the absence of product choice for the consumer.) Instead the focus is on the veterinarian sector, very close in terms of the care offered, but which is characterised by the sale of more or less complex products. The methodology used to test the research hypotheses will now be discussed.

\section{Hypotheses}

Four groups of hypotheses are proposed to study the contribution of elements of service to client satisfaction, the client's commitment to the vet clinic and the client's share of purchase in this practice.

$\mathrm{H}_{1}$ : The service elements show different modes of contribution to consumer satisfaction in a complex service area.

$\mathrm{H}_{1 \mathrm{a}}$ : Among the set of elements whose weight is fluctuating, 
there are elements strongly contributing to the client level of dissatisfaction when they are negatively evaluated and weakly contributing to the client level of satisfaction when they are positively evaluated (basic elements).

$\mathrm{H}_{1 \mathrm{~b}}$ : Among the set of elements whose weight is fluctuating, there are elements strongly contributing to the client level of satisfaction when they are positively evaluated and weakly when they are negatively evaluated (plus elements).

$\mathrm{H}_{1 \mathrm{c}}$ : Among the set of elements whose weight is stable, there are elements strongly contributing to the client level of satisfaction whenever they are positively or negatively evaluated (key elements).

$\mathrm{H}_{1 \mathrm{~d}}$ : Among the set of elements whose weight is stable, there are elements weakly contributing to the client level of satisfaction whenever they are positively or negatively evaluated (secondary elements).

$\mathrm{H}_{2}$ : The tetraclass model permits the categorisation of complex service elements according to their contribution modes to commitment towards the service supplier.

$\mathrm{H}_{3}$ : The tetraclass model permits the categorisation of complex service elements according to their contribution modes to the share of purchase in the service supplier.

$\mathrm{H}_{4}$ : The contribution modes of service elements to satisfaction, commitment and share of purchase are different.

\section{Methodology}

This section reviews the reasons why this domain of application was chosen for this research, and then goes on to discuss the data collection methodology and finishes with the data analysis technique.

\section{Domain of application}

The selected domain of application is the one of services offered by vet clinics to pet owners. The service includes, of course, medical or surgical care (with several levels of complexity from vaccination to complex surgery), but also the selling of products (antiparasitic, hygiene products, commercial pet food etc), the latter also being dispensed through other channels (pharmacies, pet shops, garden centres and supermarkets). This sector has been chosen because of some of its characteristics: strong pet owner involvement in the care dispensed to the animal, complex service offers, strong affective bonds in the tripartite client-pet-clinic relationships, strong competition (even between practitioners), unregulated prices, presence of generalist practitioners and also of specialists (freely chosen by clients) and availability of medical insurance for pets which is rarely taken up by owners. For this set of reasons, the choice of a veterinarian by a pet owner frequently arises via word of mouth about the quality of the vet clinic services. This way of choosing a clinic favours disloyalty as customers will tend to switch vet clinics.

\section{Data collection}

Data collection was phased in two steps: a qualitative step followed by a quantitative one.

The qualitative step was designed to collect the elements of service involved in the pet owner's perception of clinic service quality, whatever the service 
evaluated by the client. Semi-directed interviews were conducted with 18 pet owners and five vet practitioners. These were run in distinct geographical areas (Nantes, Paris, Nice and London) in order to take into account local specificities (for instance, absence of a car park at the clinic, an important element of service for a Parisian client and not cited by a provincial one), without questioning the individual choice models. During this phase, 92 different elements of service were selected and regrouped in nine distinct categories (the list of elements and of categories are in Appendix 1).

The second step, the quantitative one, consisted of administering a questionnaire made of these 92 elements of service to pet owners. Each of these 92 items were evaluated by the respondents on a six-point scale of perceived performance. Two hundred and ninety-nine auto-administered questionnaires collected during 2001 in four French clinics and in the one English one. To prevent bias in respondent selection, the methodology involved the surgery receptionists giving each existing incoming client a questionnaire (new clients, clients coming through the emergency service or at weekends were not addressed). Clients completed the questionnaire in the waiting room, just before the consultation. Once completed the questionnaires were put into a mailing box, anonymously. The in-clinic data collection lasted, on average, ten days.

The 'global satisfaction' variable was collected on a ten-point semantic-differential scale. The variable 'commitment to the clinic' was measured based on two items (resistance to substitution and purchase carry back) found in Lacoeuilhe's literature review. ${ }^{56}$ The behavioural variable of share of purchase in the clinic was measured by a direct question on the proportion of spending for the animal represented by the surgery, a pet owner being able to go to several different vet clinics. Share of purchase was self-reported because it was inaccessible any other way.

After eliminating the incomplete questionnaires, 148 questionnaires were retained.

\section{Data analysis}

The data analysis technique used was factorial correspondence analysis which was applied to satisfaction, commitment and share of purchase. The perceived performances of the 92 items were symmetrically dichotomised (responses from one to four on one hand and responses from five to six on the other) in order to distinguish the really positive evaluations from those qualified as 'negative'. The satisfaction, commitment and share of purchase scores were also split into two modalities called 'positive score' and 'negative score'. For these latter three variables, the cut-off point was identified using a classification and regression tree (CART) segmentation. This technique, close to the automatic interaction detector (AID) one, is based on the CART binary algorithm ${ }^{57}$ which identifies exactly two homogeneous sub-groups by cutting.

In this study each factorial correspondence analysis considers two variables. The first, made of the two modalities of each item (positive and negative evaluations), gathers 184 modalities (92 items times two modalities). The other, being either satisfaction, commitment or share of purchase, has two modalities (positive and negative scores). The resulting axis is thus unidimensional and gives 100 per cent of the initial variation back. 
For each of the three variables (satisfaction, commitment and share of purchase) each item is then attributed two factorial scores, the first corresponding to its negative evaluations and the second to its positive evaluations.

Three factorial mappings, one for satisfaction, one for commitment and one for share of purchase, are then elaborated. Each item is located by its two previously defined coordinates. For example, for the satisfaction mapping, the horizontal axis represents the item contribution to global satisfaction when negatively evaluated, the vertical axis being its contribution to global satisfaction when positively evaluated.

The three variables, satisfaction, commitment and share of purchase, also have their own factorial scores which are used to define the reference mark in each mapping. According to their position against this reference mark, the elements of service will be categorised as per Llosa's terminology ${ }^{58}$ in four categories: ie basic criteria, key criteria, plus criteria and secondary criteria.

The comparison of the different contribution modes (Hypothesis 4) will be made two by two: share of purchase versus satisfaction, share of purchase versus commitment and commitment versus share of purchase. The ordinal correlation coefficients for the elements of service coordinates will be calculated in order to compare the elements' positions in the three mappings.

\section{RESULTS}

\section{Test of Hypothesis 1 (Mapping in Appendix 2)}

The first mapping (service elements' contribution to satisfaction) shows that the 92 service elements do not contribute linearly to satisfaction. For example, item 'ass_pres' (presence of a receptionist) strongly contributes to dissatisfaction when negatively evaluated (horizontal axis) but slightly contributes to satisfaction when positively evaluated (vertical axis), so it is a basic criterion in the tetraclass model. Similarly, item 'att_ confo' (comfortable seats in the waiting room) slightly contributes to satisfaction whenever negatively or positively evaluated, so it is a secondary criterion in the tetraclass model. Hypothesis $\mathrm{H}_{1}$ is not disproved.

In return, contrary to Llosa, no plus criteria (slightly contributing to dissatisfaction when negatively evaluated and strongly contributing to satisfaction when positively evaluated) were found in this category of service, even though the number of basic elements is large. This outcome looks surprising because, in this category, a few elements, such as the ones linked to time (and notably 'waiting time'), were expected. The selected service area (health) or strong client involvement in this type of service may explain this result.

\section{Test of Hypothesis 2 (Mapping in Appendix 3)}

The second mapping (elements' contribution to commitment) shows that:

- the categorisation is, except for one service element, non-existent. All the service elements have the same influence on client commitment to the vet clinic;

- the elements do not contribute to commitment whenever they are negatively (horizontal axis) or positively (vertical axis) evaluated.

Hypothesis $\mathrm{H}_{2}$ is, consequently, clearly disproved. Commitment does not respond to the tetraclass model of service elements' contribution. 
Table 1: Coefficients of rank correlation, Kendall's tau

\begin{tabular}{llll}
\hline AXIS 1 & \multicolumn{2}{l}{ Tau coefficient (Kendall) } \\
SATisfaction - COMmitment & Sig. & -0.406 & 0.000 \\
SATisfaction - PURchases & Sig. & -0.306 & 0.000 \\
COMmitment - PURchases & Sig. & 0.129 & 0.068 \\
AXIS 2 & & -0.388 & 0.000 \\
SATisfaction - COMmitment & Sig. & -0.215 & 0.002 \\
SATisfaction - PURchases & Sig. & 0.151 & 0.033 \\
COMmitment - PURchases & Sig. & & \\
\hline
\end{tabular}

\section{Test of Hypothesis 3 (Mapping in Appendix 4)}

The third map (service elements' contribution to shares of purchases) shows that:

- the categorisation clearly exists: the 92 service elements do not contribute linearly to the clients' share of purchase

- there are more service elements in the two top quarters than in the two bottom ones

— this asymmetry looks complementary to that of satisfaction.

$\mathrm{H}_{3}$ is not disproved.

\section{Test of Hypothesis 4}

To test Hypothesis 4, ie that service elements' contribution to satisfaction, commitment and share of purchase differ, measures of association between service elements and the three concepts of satisfaction, commitment and share of purchase were calculated. Given the ordinal status of the variables, the Spearman and Kendall coefficients of rank correlation were used.

By reading the coefficients of rank correlation of the horizontal and of the vertical coordinates in the three mappings, it is noted that:
- on axis 1 (horizontal), the service elements have their share of purchases abscissa more positively correlated to the commitment ones (COM-PURs) than to the satisfaction ones (SAT-PURs)

- on axis 2 (vertical), the service elements similarly have their share of purchase coordinates more positively linked to the commitment ones (COM-PURs) than to the satisfaction ones (SAT-PURs).

Hypothesis $\mathrm{H}_{4}$ is not disproved: if a few service elements contribute in the same order to commitment and to share of purchase, this clearly happens less often for satisfaction and commitment or for satisfaction and share of purchase. The strongest opposition (rank anti-correlation) happens to be between satisfaction and commitment (SAT-COM) so confirming the structural difference of these two constructs.

\section{CONCLUSION AND AREAS OF FURTHER RESEARCH}

Analysis indicates that categorisation of service elements for satisfaction according to the tetraclass model is verified for a complex offer of service. This categorisation of service elements, applied in the veterinary area, therefore reveals 
Table 2: Service elements switching between satisfaction and share of purchase

\begin{tabular}{ccccccc}
\hline & \multicolumn{2}{c}{ Categorisation for share of purchase } & & \\
& Basic $\%$ & Key $\%$ & Plus \% & Secondary \% & Total \% \\
\hline Categorisation for satisfaction & & & & & \\
Basic & 2.7 & 34.2 & 56.2 & 6.8 & 100.0 \\
Key & 28.6 & 28.6 & - & 42.9 & 100.0 \\
Secondary & 16.7 & 50.0 & 8.3 & 25.0 & 100.0 \\
Total & 6.5 & 35.9 & 45.7 & 12.0 & 100.0 \\
\hline
\end{tabular}

the absence of the plus elements. It highlights the possible specificity of high involvement service offers, or the peculiarity of the medical area as a whole. Can the regulated professions be characterised by some standardisation of the peripheral services, ie existing plus elements? Can these not be linked to commercial practices prohibited in the health area? At a first glance, referring to the plus elements identified by the author of the tetraclass model in her restaurant field (service elements such as recognition, advice, lighting, temperature, waiting time and staff ambience), it cannot be said they respond to commercial practices prohibited to veterinarians. On the other hand, involvement in pet health, where the perceived risk in choosing the wrong vet is high, may make the basic type of elements more salient than the plus ones. A future area of research would be duplication of this study in the human health area to confirm or disprove this absence of criteria.

The second finding concerns the results of the categorisation of service elements for client commitment and share of purchase in this area. If the methodology used has enabled categorisation of service elements for share of purchase, this categorisation has been shown to be impossible for client commitment. The consequence of this observation concerns the managerial implications of service elements: the strategy of improving on a few service elements on the basis of their categorisation for satisfaction may not be the most relevant for commitment and share of purchases. Further research should analyse the criteria simultaneously intervening on satisfaction and share of purchase.

A third finding concerns the nature of the basics elements for dissatisfaction. In this work, the veterinary-linked criteria appear to be the basics. This is in line with the suggestion of the tetraclass model's author who saw elements of the core service (in Eiglier and Langeard's ${ }^{59}$ view) as part of the basics.

A fourth finding concerns the relative position of the elements in the selected area. As far as satisfaction is concerned, the elements linked to waiting are categorised as secondary in the vet service but as plus by Llosa in the 'restaurant' service experience. Would this waiting not be a basic in the fast-food area? This may be due to a limitation of the tetraclass model in which categorisations depend, among other things, on the type and the number of the attributes considered (relative categorisation).

Another area of research would seek to explain and predict why some elements go from one category across to another when switching from satisfaction to share of purchase, as shown in Table 2. In particular, can the complementarity noted in Hypothesis 3, between the 
categorisation for satisfaction and the one for share of purchase, be confirmed? The managerial applications of this latter point would be huge.

In terms of methodology, a comparison of the tetraclass model technique with another one, eg structural equation modelling, to see if the data support all causal directions as implied by the tetraclass model, would be interesting.

Lastly, taking into consideration a few segmentation variables (like clients' length of time with the service supplier, client involvement, sociodemographic criteria, values) by, for instance, plotting them as passive variables in the correspondence analysis, would appear necessary in order to analyse more deeply the findings of this study.

\section{Acknowledgment}

The authors want to thank Mr Alexander Arpino for his generous contribution to the translation of this paper.

\section{References}

1 Laban, J. (1979) 'Contribution à la mesure de la fidélité du consommateur: application au domaine des services automobiles', Thèse de Doctorat d'Etat en Sciences de Gestion, Université de Droit, d'Economie et des Sciences d'Aix-Marseille.

2 Engel, J. F., Blackwell, R. D. and Miniard, P. W. (1980) 'Consumer behaviour', 6th edn, The Dryden Press, Chicago II.

3 Dufer, J. and Moulins, J. L. (1989) 'La relation entre la satisfaction du consommateur et sa fidélité à la marque: un examen critique', Recherche et Applications en Marketing, Vol. 4, No. 2, pp. 21-36.

4 Bloemer, J. and Kasper, H. (1993) 'Brand loyalty and brand satisfaction: The case of buying audio cassettes anew in Netherlands', Proceedings of the 22th EMAC Conference, Barcelona, Vol. 1, pp. 183-200.

5 Llosa, S. (1996) 'Contributions à l'étude de la satisfaction dans les services', Thèse de Doctorat en Sciences de Gestion, I.A.E. Aix-Marseille.

6 Llosa, S. (1997) 'L'analyse de la contribution des éléments du service à la satisfaction: un modèle tétraclasse', Décisions Marketing, Vol. 1, No. 10, pp. 81-88.

7 Bartikowski, B. and Llosa, S. (2001) 'De la théorie du poids fluctuant des éléments dans la satisfaction à la mesure. Comparaison empirique de quatre méthodes', Proceedings de la Conférence de
l'Association Française du Marketing, Deauville, IAE de Caen-Basse Normandie.

8 Lichtlé, M.-C., Plichon, V. and Llosa, S. (2001) 'La contribution des éléments d'une grande surface alimentaire à la satisfaction du client', Proceedings de la Conférence de l'Association Française du Marketing, Deauville, IAE de Caen-Basse Normandie.

9 Audrain, A.-F. and Evrard, Y. (2001) 'Satisfaction des consommateurs: pricisions conceptuelles',

Proceedings de la Conférence de l'Association Française du Marketing, Deauville, IAE de Caen-Basse Normandie.

10 Garbarino, E. and Johnson, M. S. (1999) 'The different roles of satisfaction, trust, and commitment in customer relationships', Journal of Marketing, Vol. 63, pp. 70-87.

11 Jacoby, J. and Kyner, D. B. (1973) 'Brand loyalty vs. repeat purchasing behaviour', Journal of Marketing Research, Vol. 10, February, pp. 1-9.

12 Rust, R. T. and Zahoric, A. J. (1993) 'Customer satisfaction, customer retention, and market share', Journal of Retailing, Vol. 69, No. 2, pp. 193-215.

13 McLaughlin, E. W. and Wittink, D. R. (1998) 'A model of consumer perceptions and store loyalty intentions for a supermarket retailer', Journal of Retailing, Vol. 74, No. 2, pp. 223-245.

14 Rust, R., Zahoric, A. and Keiningham, T. (1995) 'Return on quality (ROQ): Making service quality financially accountable', Journal of Marketing, Vol. 59, No. 4 , pp. $58-70$.

15 Cadotte, E. R. and Turgeon, N. (1988) 'Dissatisfiers and satisfiers: Suggestions for consumer complaints and compliments', Journal of Consumer Satisfaction, Dissatisfaction and Complaining Behaviour, Vol. 1, pp. 74-79.

16 Herzberg, F., Mausner, B. and Snyderman, B. (1959) 'The motivation to work', John Wiley and Sons, Inc., New York.

17 Swan, J. and Combs, J. (1976) 'Product performance and consumer satisfaction: A new concept', Journal of Marketing, Vol. 40, No. 1, pp. 25-33.

18 See Llosa (1997) op. cit.

19 See Llosa (1996) op. cit.

20 See Bartikowski and Llosa (2001) op. cit.

21 See Llosa (1997) op. cit.

22 See Llosa (1996) op. cit.

23 See Lichtlé et al. (2001) op. cit.

24 See Rust et al. (1995) op. cit.

25 Anderson, E. W., Fornell, C. and Lehmamn, D. R. (1994) 'Customer satisfaction, market share and profitability: Findings from Sweden', Journal of Marketing, Vol. 58, No. 3, pp. 53-66.

26 Bolton, R. N. and Drew, J. H. (1994) 'Linking customer satisfaction to service operations and outcomes', in Rust, R. and Oliver, R. L. (eds) 'Services quality, new directions in theory and practice', Sage Publications, London.

27 Anderson, E. W. and Sullivan, M. W. (1993) 'The antecedents and consequences of customer satisfaction for firms', Marketing Science, Vol. 12, No. 2, pp. 125-143. 
28 Fornell, C. (1992) 'A national customer satisfaction barometer: The Swedish experience', Journal of Marketing, Vol. 56, pp. 6-21.

29 Tse, D. K and Wilton, P. C. (1988) 'Models of consumer satisfaction formation: An extension', Journal of Marketing Research, Vol. 25, No. 2, pp. 204-212.

30 Swan, J. E. and Trawick, I. F. (1981) 'Disconfirmation of expectations and satisfaction with a retail service', Journal of Retailing, Vol. 57, No. 3, pp. 49-67.

31 Oliver, R. L. (1980) 'Cognitive, affective and attribute bases of the satisfaction response', Journal of Consumer Research, Vol. 20, No. 3, pp. 418-430.

32 Oliver, R. L. and Linda, G. (1980) 'Effect of satisfaction and its antecedents on consumer preference and intention', Advances in Consumer Research, Vol. 8, pp. 88-93.

33 Hallowell, R. (1996) 'The relationship of customer satisfaction, customer loyalty and profitability: An empirical study', International Journal of Service Industry Management, Vol. 7, No. 4, pp. 27-42.

34 Boulding, W., Kalra, A., Staelin, R. and Zeithaml, V. (1993) 'A dynamic process model of service quality: From expectations to behavioural intentions', Journal of Marketing Research, Vol. 30, No. 1, pp. 7-27.

35 Bearden, W. O. and Teel, J. E. (1983) 'Selected determinants of consumer satisfaction and complaints records', Journal of Marketing Research, Vol. 20, No. 1, pp. 21-28.

36 See Oliver (1980) op. cit.

37 See Bloemer and Kasper (1993) op. cit.

38 See Garbarino and Johnson (1999) op. cit.

39 Anderson, E. W. and Mittal, V. (1999) 'The satisfaction-profit chain: How solid are the links?', Research Paper, The National Quality Research Center, University of Michigan Business School.

40 Jones, T. O. and Sasser, W. E. (1995) 'Why satisfied customers defect', Harvard Business Review, November-December, pp. 88-99.

41 Ngobo, P-V. (2000) 'Satisfaction des clients et part de marché de l'entreprise: un réexamen au regard de récentes avancées théoriques', Recherche et Applications en Marketing, Vol. 15, No. 2, pp. 21-41.

42 See Anderson and Mittal (1999) op. cit.

43 Oliva, T. A., Oliver, R. L. and Macmillan, I. C.

(1992) 'A catastrophe model for developing service satisfaction strategies', Journal of Marketing, Vol. 56, No. 3, pp. 83-98.

44 Coyne, K. P. (1989) 'Beyond service fads meaningful strategies for the real world', Sloan Management Review, Vol. 30, No. 4, pp. 69-76. 45 See Audrain and Evrard (2001) op. cit. 46 See Garbarino and Johnson (1999) op. cit. 47 Doney, P. M. and Cannon, J. P. (1997) 'An examination of the nature of trust in buyer-seller relationships', Journal of Marketing, Vol. 61, No. 4, April, pp. 35-51.

48 See Jones and Sasser (1995) op. cit.

49 Morgan, R. M. and Hunt, S. D. (1994) 'The commitment-trust theory of relationship marketing', Journal of Marketing, Vol. 58, No. 3, July, pp. 20-38.

50 Moorman, C., Zaltman, G. and Deshpandé, R. (1992) 'Relationships between providers and users of market research: The dynamics of trust within and between organizations', Journal of Marketing Research, Vol. 29, August, pp. 314-328.

51 See Rust et al. (1995) op. cit.

52 See Morgan and Hunt (1994) op. cit.

53 See Rust and Zahoric (1993) op. cit.

54 Chesnut, R. W. and Jacoby, J. (1978) 'Brand loyalty: Measurement and management, J. Wiley and Sons, New York.

55 See Ngobo (2000) op. cit.

56 Lacoeuilhe, J. (2000) 'Le concept d'attachement: contribution à l'étude du rôle des facteurs affectifs dans la formation de la fidilité à la marque', Thèse de Doctorat en Sciences de Gestion, Université Paris XII Val de Marne.

57 Breiman, L., Friedman, J. H., Olshen, R. A. and Stone, C. J. (1984) 'Classification and regression trees', Wadsworth, Belmont California.

58 See Llosa (1996) op. cit.

59 Eiglier, P. and Langeard, E. (1988) 'Servuction, Le marketing des services', McGraw-Hill, Paris. 


\section{APPENDIX 1}

List of selected service elements

\begin{tabular}{|c|c|c|c|}
\hline acc_indi & Access: Signs to reach the clinic & hos_confo & Hospitalisation: Comfort for animal \\
\hline acc_park & Access: Car Park & hos_evol & Hospitalisation: Information on health status \\
\hline acc_rapi & Access: Quickness & hos_expli & Hospitalisation: Clear explanations \\
\hline acc_secu & Access: Security for my animal & hos_nouv & Hospitalisation: News by telephone \\
\hline ass_affec & Assistants: Affection for my animal & hos_suiv & Hospitalisation: Follow up \\
\hline ass_amou & Assistants: Likes animals & hos_visi & Hospitalisation: See my animal \\
\hline ass_badg & Assistants: Badge & inf_acqu & Information: Acquiring a pet \\
\hline ass_com & Assistants: Commercial competences & inf_assu & Information: On pet insurance \\
\hline ass_doss & Assistants: Access to my animal file & inf_elev & Information: Pet education \\
\hline ass_douc & Assistants: Gentleness with my animal & inf_gard & Information: Pet boarding \\
\hline ass_ecou & Assistants: Listening capacities & inf_mort & Information: On my pet death \\
\hline ass_inter & Assistants: Interest for my animal & inf_nouv & Information: On new products \\
\hline ass_patie & Assistants: Patience & inf_perd & Information: Lost pets \\
\hline ass_poli & Assistants: Politeness & inf_pers & Information: Customisation \\
\hline ass_pres & Assistants: Present at reception & inf_prod & Information: On products \\
\hline ass_rassu & Assistants: Confidence & inf_sail & Information: Pet reproduction \\
\hline ass_souri & Assistants: Smile & inf_serv & Information: On services \\
\hline ass_tech & Assistants: Technical competences & inf_spec & Information: On the practice specialisations \\
\hline ass_tenu & Assistants: Uniform cleanness & inf_voya & Information: Travelling with my pet \\
\hline att_affi & Waiting room: Posters & tel_clart & Telephone: Clear answers \\
\hline att_anno & Waiting room: Bulletin board & tel_decr & Telephone: Quick answering \\
\hline att_brui & Waiting room: Noise & tel_disp & Telephone: Availability \\
\hline att_clart & Waiting room: Brightness & tel_rapp & Telephone: Call me back \\
\hline att_confo & Waiting room: Comfortable seats & tel_rdv & Telephone: Getting a convenient \\
\hline att_deco & Waiting room: Decoration & & appointment \\
\hline att_delai & Waiting room: Information on waiting time & vet_affec & Vet: Affection for my pet \\
\hline att_dispo & Waiting room: Availability of seats & vet_amou & Vet: Loves pets \\
\hline att_duree & Waiting room: Waiting time & vet_arge & Vet: Balance between money/pet dedication \\
\hline att_enfa & Waiting room: Children's area & vet_choi & Vet: Obtaining my preferred vet \\
\hline att_info & Waiting room: Information & vet_com & Vet: Commercial competences \\
\hline att_isol & Waiting room: Separate areas & vet_cons & Vet: Time spent in consultation \\
\hline att_musi & Waiting room: Music & vet_cons & Vet: Advice \\
\hline att_occup & Waiting room: Occupations & vet_deci & Vet: Information to help me decide \\
\hline att_odeu & Waiting room: Odours & vet_devo & Vet: Dedication for my pet \\
\hline att_ponc & Waiting room: Punctuality & vet_douc & Vet: Gentle with my pet \\
\hline att_prop & Waiting room: Cleanliness & vet_expli & Vet: Clear explanations \\
\hline att_revu & Waiting room: Magazines & vet_guer & Vet: Speed of recovery \\
\hline att_temp & Waiting room: Temperature & vet_hon & Vet: Honesty \\
\hline exe_assi & Exteriors: Seats & vet_inter & Vet: Concerned by pets \\
\hline exe_heur & Exteriors: Clear indication of opening hours & vet_just & Vet: Correct diagnosis \\
\hline exe_prop & Exteriors: Cleanliness & vet_poli & Vet: Politeness \\
\hline exe_spec & Exteriors: Indication of vets specialities & vet_prop & Vet: Cleanliness \\
\hline fin_clart & End of visit: Clear bills & vet_rapi & Vet: Quick diagnosis \\
\hline fin_devi & End of visit: Quotes & vet_rassu & Vet: Trusty \\
\hline fin_expli & End of visit: Explanations on bill & vet_souri & Vet: Smiling \\
\hline fin_qpri & End of visit: Quality/price ratio & vet_tech & Vet: Technical competence \\
\hline
\end{tabular}




\section{APPENDIX 2}

Categorisation of service elements in four classes - basics, plus, keys and secondaries - according to their coordinates on the axis of contributions to dissatisfaction when negatively evaluated (X-axis) and their coordinates on the axis of contributions to satisfaction when positively evaluated (Y-axis)

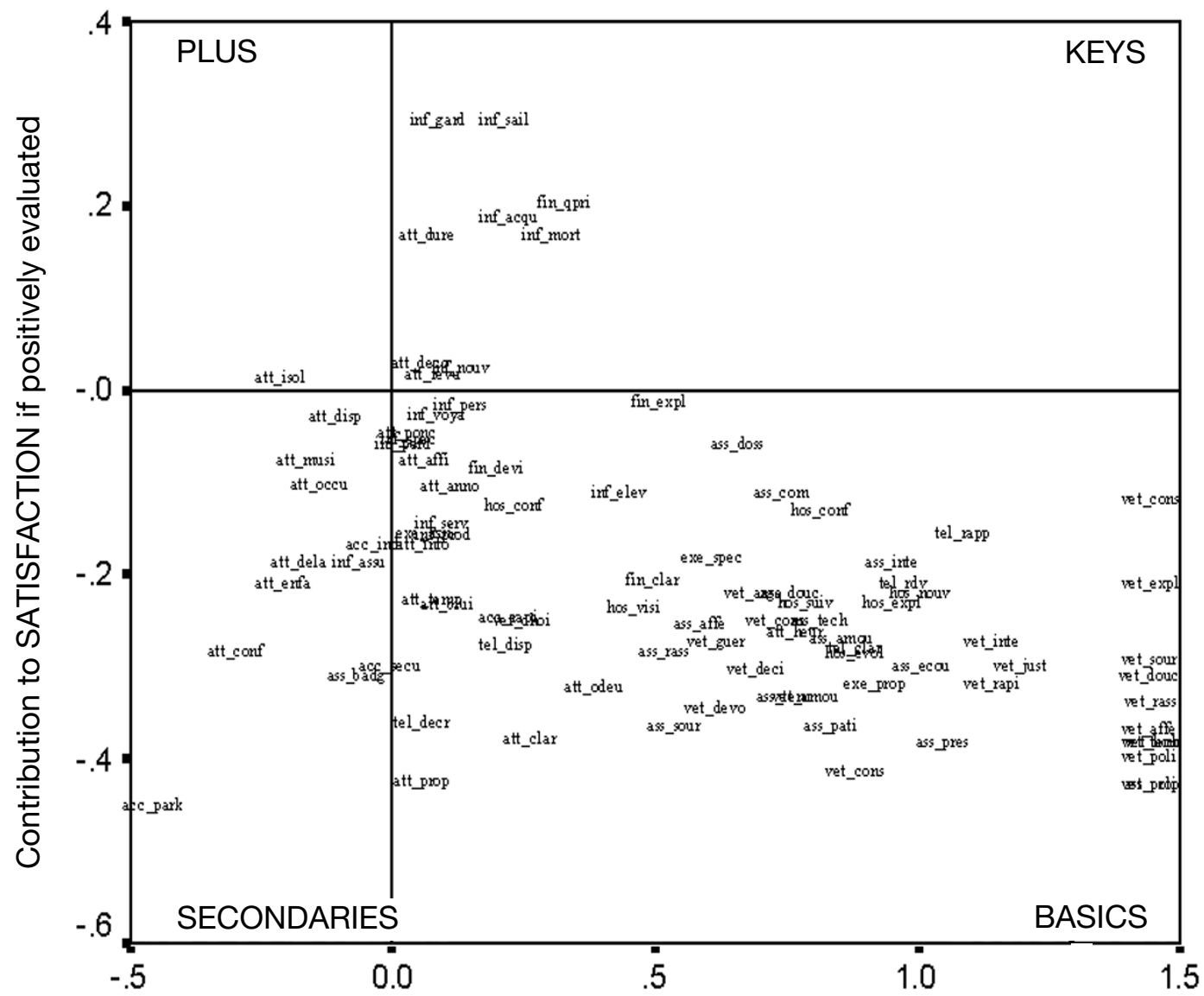

Contribution to SATISFACTION if negatively evaluated 


\section{APPENDIX 3}

Categorisation of service elements for the client commitment variable

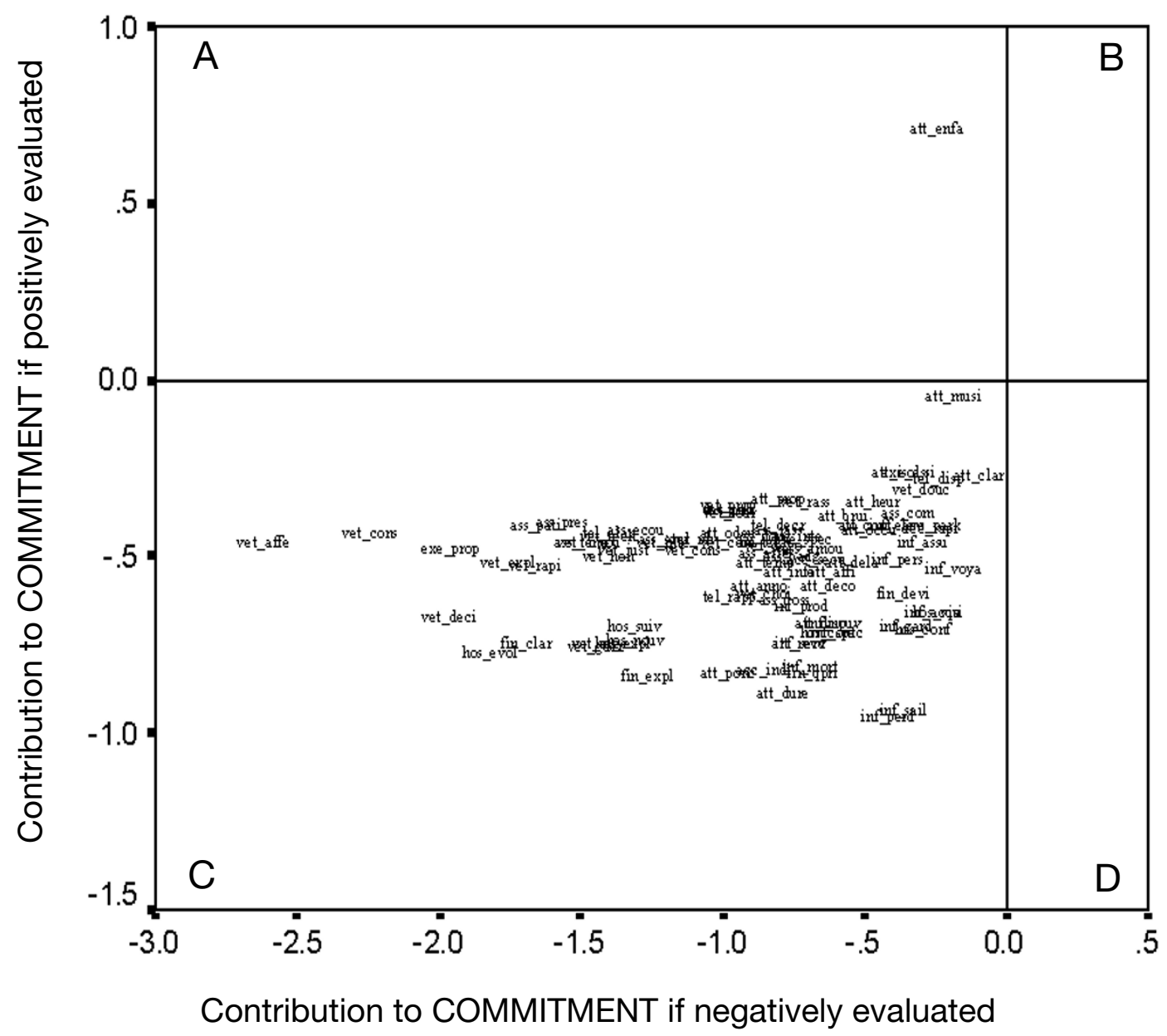

